\title{
A Guerra Holandesa nas relaçóes de sucessos seiscentistas
}

\author{
Kleber Clementino ${ }^{1 *}$ \\ ${ }^{1}$ Universidade Federal Rural de Pernambuco, Pernambuco, Brasil.
}

\section{RESUMO}

Na Alta Idade Moderna (séculos XVI e XVII), a composição de relaçóes de sucessos converteu-se em instrumento estratégico da ação política das nações em conflito e das disputas por poder no interior dos impérios ibéricos. Este artigo propóe-se a analisar a narrativa da Guerra Holandesa (1624-1654) contida nas relaçóes de sucessos luso-espanholas. Estudam-se os contextos e pressóes políticas a que esses papéis respondiam, o enredo que coletivamente formulam e, sobretudo, as diversas vozes dos grupos de interesse por detrás da escrita e impressão de panfletos, nos diferentes momentos e cenários da luta.

Palavras-chave: relações de sucessos; Guerra Holandesa; discurso político; escrita da história; retórica.

\section{The Dutch War in the XVII ${ }^{\text {th }}$ century relaçóes de sucessos}

\section{ABSTRACT}

In Early Modern Age (XVIth and XVIIth centuries), the writing of 'relaçôes de sucessos' [relations of events] became a strategic instrument in conflicting nations' policies and in disputes for power across Iberian empires. This article aims to analyse the narrative of the Dutch War (1624-1654) found in Spanish-Portuguese relaçóes de sucessos. It scrutinizes the contexts and political pressures to which these papers responded, the plotline they collectively formulate. Moreover, it focuses particularly on the voices of groups of interest behind the writing and printing of these pamphlets, in different moments and settings of the war. Keywords: chronicles; Dutch War; political discourse; writing of history, rhetoric.

DOI: http://dx.doi.org/10.1590/2237-101X02004109

Artigo recebido em 12 de abril de 2018 e aceito para publicação em 14 de outubro de 2018.

* Professor da Universidade Federal Rural de Pernambuco/Departamento de História, Recife / PE — Brasil.

E-mail: kleberclementino@hotmail.com. ORCID: https://orcid.org/0000-0001-7972-0008. 


\section{La Guerra Holandesa en las relaciones de sucesos del siglo XVII}

\section{RESUMEN}

En la Alta Edad Moderna (siglos XVI y XVII), la composición de las relaciones de sucesos se convirtió en un instrumento estratégico de acción política de las naciones en conflicto y de las disputas por poder en el interior de los imperios ibéricos. Este artículo se propone analizar la narrativa de la Guerra Holandesa (1624-1654) contenida en las relaciones de sucesos luso-españolas. Se estudian los contextos y presiones políticas a que esos papeles respondían, el enredo que colectivamente formulaban y, sobre todo, las diversas voces de los grupos de interés por detrás de la escritura e impresión se panfletos en los diferentes momentos y escenarios de la lucha.

Palabras clave: relaciones de sucesos; Guerra Holandesa; discurso político; escritura de la historia; retórica.

\section{Introdução}

No século XVII, a escrita da história foi uma forma de fazer não só a política, mas às vezes a própria guerra, por outros meios. A Guerra Holandesa (1624-1654), travada no Atlântico Sul entre as monarquias ibéricas e as Províncias Unidas dos Países Baixos, como ramificação da Guerra dos Oitenta Anos (1568-1648), impactou o mundo luso-castelhano econômica, política e culturalmente. Ao tempo em que se travaram entreveros em Flandres, na Lombardia, no Brasil e na costa africana, atores envolvidos nesses conflitos investiram na difusão de panfletos, ${ }^{1}$ oferecendo ao público versôes convenientes dos eventos, elegendo episódios e personagens, aqui os enaltecendo, ali os demonizando. Converter a guerra em texto impunha delicada operação retórica, face ao desafio de aliciar o público para certa agenda política ou para a edificação de memória laudatória de determinado evento e grupo. Há uma história da guerra inscrita nas relaçóes de sucessos, peculiar e pouco examinada.

É no contexto de proliferação da cultura escrita que se trava a Guerra Holandesa, novidade que altera os termos em que se desdobram os entrechoques internacionais. Outros con-

\footnotetext{
${ }^{1}$ Rodrigues enumera seis dezenas de panfletos relativos à presença neerlandesa no Brasil e na África. RODRIGUES, J. Honório. Historiografia e bibliografia do domínio holandês no Brasil. Rio de Janeiro: Dep. de Imprensa Nacional, 1949. pp. 190 e ss. Schwartz e Magalhães acrescentarão à lista alguns papéis inéditos. SCHWARTZ, Stuart. B. The Voyage of the Vassals: Royal Power, noble obligations and merchant capital before the Portuguese restoration of independence (1624-1640). The American Historical Review, v. 96, n. 3, p. 735-762, jun. 1991; MAGALHĀES, Pablo A. I. Equus rusus: a Igreja Católica e as Guerras Neerlandesas na Bahia (1624-1654). Tese (Doutorado em História) — Programa de Pós-graduação, Salvador, 2010.
} 
flitos, como a Guerra dos Trinta Anos (1618-1648) e a Guerra de Restauração Portuguesa (1640-1668), serão pelejados, ao mesmo tempo, no plano da confrontação militar e no da "guerra de papéis". A arregimentação das forças necessárias à vitória impunha contínua investida retórica, capaz de sustentar o moral dos aliados e justificar a iniciativa bélica. Bouza Álvarez se refere à Europa gutemberguiana como "civilização escrita", na qual manuscrito e impresso desempenharão funçôes cruciais e incidirão sobre a administração, as práticas de sociabilidade e as refregas por poder. Argumenta que os Estados na Alta Modernidade acharam na palavra escrita suporte mais eficaz para o despacho de suas ordens e vislumbraram nas grandes tiragens e nos preços em queda da imprensa em expansão a chance de veicular a mais largas audiências discursos favoráveis a seu processo de centralizaçấo. ${ }^{2}$ Casos do uso político da imprensa e de panfletos no período foram estudados por autores como Megiani e Rault. ${ }^{3}$

Tais análises, centradas nos usos do escrito por parte do Estado moderno, podem ser estendidas a outros atores. Grupos de interesses fora dos centros decisórios igualmente exploraram os potenciais da imprensa, fosse para resistir ao empuxo centrípeto das monarquias - caso das classes nobres atacadas em suas prerrogativas feudais - fosse para angariar visibilidade e abrir trilhas de ascensão, explorando as promessas de recompensa por serviços prestados às casas reinantes. A literatura panegírica se fez corriqueira na cultura do Seiscentos, como tática no interior desse esforço de visibilização. ${ }^{4}$ Tal caminho foi, decerto, explorado pela nobreza ibérica, mas também por parvenus como João Fernandes Vieira e por outros de mais áureo berço, como Salvador Correia de Sá e os Albuquerque, família donatarial de Pernambuco. Todos, tendo-se engajado na luta contra os neerlandeses, investiram na autopromoção, na "fama" calcada na simbólica do heroísmo cavalheiresco.

A história da Guerra Holandesa é, essencialmente, um legado do século XVII. As revisitaçôes às narrativas do Seiscentos, nos séculos XVIII a XX, por autores como Rocha Pitta, Loreto Couto e outros, tenderam a preservar as soluçôes discursivas dos primeiros autores para a conversão do real em texto. $\mathrm{O}$ panteão dos heróis e a lista dos vilóes, a sequência de

\footnotetext{
${ }^{2}$ BOUZA ÁLVAREZ, Fernando J. Del escribano a la biblioteca: la civilización escrita europea en la Alta Edad Moderna (siglos XV-XVIII). Madri: Síntesis, 1997. p. 9-23. BOUZA ÁLVAREZ, Fernando J. Portugal no tempo dos Filipes (1580-1668). Lisboa: Cosmos, 2000. A amplitude do público leitor europeu do Seiscentos, bem como a existência de uma "opinião pública" nos centros urbanos europeus do século XVII são temas debatidos em trabalhos como USUNÁRIZ, Jesus M. América, la política internacional europea y las "relaciones de sucesos" españolas tras los tratados de Westfalia. Rev. Chilena de literatura, Santiago, n. 85, p. 179201, nov. 2013. MARQUILHAS, Rita. A faculdade de letras: leitura e escrita em Portugal no século XVII. Lisboa: Imprensa Nacional — Casa da Moeda, 2000.

${ }^{3}$ MEGIANI, Ana Paula Torres. O rei ausente: festa e cultura política nas visitas dos Filipes a Portugal (15811619). São Paulo: Alameda, 2004. RAULT, Didier. La información y su manipulación en las relaciones de sucesos. Encuesta sobre dos relatos de batallas navales entre españoles y holandeses (1638). Rev. Criticón, Toulouse, n. 86, p. 97-115, 2002.

${ }^{4}$ BEBIANO, Rui. A pena de Marte: escrita da guerra em Portugal e na Europa (sécs. XVI-XVIII). Coimbra: Minerva, 2000. p. 273-286.
} 
episódios memoráveis e mesmo a periodização consagrada, vigente ainda em estudos recentes, mantém a narratio seiscentista - inscrita em relaçóes de sucessos, relaçóes historiais e obras históricas vindas a lume entre 1625 e 1698 - em suas linhas gerais. ${ }^{5}$ No século XIX, Varnhagen, apesar da ácida crítica que dirige à "parcialidade" das fontes seiscentistas em sua Historia das lutas com os Hollandezes no Brazil (1871), conserva, em grande medida, as representaçóes de obras como a Jornada dos Vassalos da Coroa de Portugal, O valeroso Lucideno e as Memorias diarias de la guerra del Brasil — as quais, mesmo quando da lavra de testemunhas do conflito, dialogam com relaçôes de sucessos que as precederam. ${ }^{6} \mathrm{~A}$ produção de relações de sucessos é apenas um dos dispositivos da vasta operação de historicização do evento, de ordinário redigidas na primeira hora ou em tempos próximos aos eventos, e por isso servindo de fontes para as relaçóes historiais e histórias posteriores. ${ }^{7}$ Esse legado das narrativas seiscentistas na construção da memória da Guerra Holandesa, todavia, não será o foco da presente análise.

A história contada pelas relações do período 1625-1654 diverge, em aspectos cruciais, daquela contida nas obras consagradas publicadas depois, no mesmo século. Nem todas as vozes que se fizeram ouvir por meio dos folhetos avulsos permaneceram audíveis, quando tais relatos foram retomados e filtrados para a escrita de obras de maior fôlego. Algumas foram matreiramente abafadas. Com base apenas nas relaçóes de sucessos, Fernandes Vieira, o autoproclamado líder da Insurreição Pernambucana (1645-1654), tornar-se-ia figura irrelevante na memória dos fatos. As batalhas das Tabocas e de Casa Forte, vencidas sob sua batuta, jamais teriam obtido o destaque que vieram a assumir, pois as primeiras relaçóes o ignoraram e foi preciso promover "narrativas vieirianas" que lhe divulgassem o heroísmo. Assim, uma virtual história da Guerra Holandesa com base apenas nas relaçóes de sucessos traria, sob muitos aspectos, um enredo distinto do evento - no limite, contariam outra guerra. Reler a versão inscrita neste repertório específico de fontes, como nos propomos aqui, permitirá examinar algumas das forças políticas em colisão, naquilo que fizeram reverberar e fixar, e daquilo que forcejaram por fazer esquecer.

\footnotetext{
${ }^{5}$ CLEMENTINO, Kleber. Politica e historiografia nas narrativas lusocastelhanas seiscentistas da Guerra Holandesa. Tese (Doutorado em História) - Programa de Pós-graduação, Universidade Federal de Pernambuco, Recife, 2016. Tende-se a distinguir a conquista da WIC em Salvador, em 1624-1625, da "Guerra de Pernambuco", de 1630 a 1654, fazendo jus ao plural "guerras holandesas", que não utilizamos aqui. A "Guerra de Pernambuco", ademais, costuma ser periodizada nas fases: 1630-1637, "guerra velha"; 1637-1644, pax nassoviana e 1645-1654, eclosão e vitória da "Guerra da Liberdade Divina", recorte e nomenclatura inscritos em alguns dos textos do Seiscentos.

${ }^{6}$ CLEMENTINO, Kleber. Heródoto de mentirinha: Varnhagen, a escrita da história da Guerra Holandesa e seu diálogo com as obras dos séculos XVII, XVIII e XIX. Clio, n. 32.2, p. 128-152, jul./dez. 2018. MELLO, Evaldo Cabral de. Rubro veio: o imaginário da Restauração Pernambucana. Sáo Paulo: Alameda, 2008. p. 63-87 discute também o legado nas obras seiscentistas no debate erudito dos séculos XVIII e XIX.

${ }^{7}$ As diferenças entre as relaçóes de sucessos, relaçôes historiais e obras históricas, quanto a seus característicos editoriais e importância política, são discutidas em CLEMENTINO, Kleber. Política e historiografia nas narrativas lusocastelhanas seiscentistas da Guerra Holandesa, op. cit.
} 


\section{As relaçóes de sucessos}

A relaçam é gênero cujas primícias datam do Medievo e que amadurece no alvorecer da Modernidade. Remonta à prática de publicização de epístolas particulares, nas quais o emissor — soldado, viajante, missionário — registra testemunho socialmente relevante: a chamada "carta-relação" que, pelo curioso do conteúdo, é posta em circulação. ${ }^{8}$ Relaçôes de festejos, de cercos bélicos ou de tragédias marítimas maturam, ao longo do Quinhentos, uma identidade editorial e linguagem própria: ligeira, direta, alheia à gramática das obras eruditas vinculadas ao humanismo. Não por acaso, alguns folhetos da Guerra Holandesa conservarão o formato arcaico da "carta-relaçáo", trazendo saudaçóes e notícias da saúde dos remetentes, embora outras se dirigissem já a um público genérico.

A difusão da imprensa amplia os usos desses panfletos, que, de ordinário, aparecem em pliegos sueltos de três a quinze páginas, com editoração de baixo custo e papel de qualidade inferior. Compradas, lidas (por elementos de diversas classes sociais) ou às vezes ouvidas em voz alta, as relaçóes satisfaziam necessidades de informar, entreter e influenciar a opinião pública nos espaços urbanos em crescimento. É, pois, uma "literatura de consumo", dinamizada por agendas políticas, em meio a partidos em concorrência. Texto que se quer noticioso, não ambiciona a posteridade e admite-se perecível, acha-se alardeado nas praças, nas casas impressoras ou nas sacolas dos caixeiros de "folhetos pello meudo", rumando para as vilas mais distantes. ${ }^{10} \mathrm{~A}$ urgência de fazer-se retratar em tintas favoráveis, nas competiçôes por poder na Europa e no ultramar, é o combustível propulsor dessas relaçóes de sucessos. $\mathrm{O}$ aprimoramento dos sistemas postais e das técnicas de navegação possibilitavam, pela primeira vez em larga escala, a difusão de novas de interesse geral, ${ }^{11}$ permitindo ampla margem de manobra aos propagadores.

Não constituem uma imprensa periódica, pois, até meados do século XVII, emergem apenas de modo ocasional. Todavia são vistos como precursores das gazetas regulares, a

\footnotetext{
${ }^{8}$ PENA SUEIRO, Nieves. Estado de la cuestión sobre el estudio de las Relaciones de sucesos. Rev. Pliegos de Bibliografia, Madri, n. 13, p. 1-19, 1ํsemestre de 2001. BEGAND, Patrick (Ed.). Las relaciones de sucesos: relatos fácticos, oficiales y extraordinarios. Besançon: Presses Universitaires de Franche Comté, 2006. MEGIANI, Ana Paula Torres. Contar coisas de todas as partes do mundo: as Relaciones de Sucesos e a circulação de notícias escritas no período filipino. In: ALMEIDA, Suely C. C.; RIBEIRO, Marília de Azambuja et al. (Org.). Cultura e sociabilidades no mundo atlântico. Recife: Ed. Universitária da UFPE, 2012.

${ }^{9}$ A existência de uma opiniáo pública já no século XVII, contrariando a tese de Habermas de que esta só teria emergido no Setecentos, é defendida pela maioria dos estudiosos das relaçóes altomodernas, como por exemplo em USUNÁRIZ, Jesus M. América, la política internacional europea y las "relaciones de sucesos" españolas tras los tratados de Westfalia, op. cit., p. 180. Ver também MELLO, Evaldo Cabral de. O negócio do Brasil: Portugal, os Países Baixos e o Nordeste (1641-1669). Rio de Janeiro: Topbooks, 1998, p. 121-122.

${ }^{10}$ Como os "cegos papelistas" mencionados em CAROLINO, Luís Miguel. A escrita celeste: almanaques astrológicos em Portugal nos séculos XVII e XVIII. Rio de Janeiro, Acess: 2002.

${ }^{11}$ ETTINGHAUSER, Henry. The News in Spain: Relaciones de sucesos in the reigns of Philip III and IV. European History Quarterly, v. 14, p. 1, 1984.
} 
partir do conceito de "protoperiodismo" adotado por autores como Sousa e Lanciani. ${ }^{12}$ Tal como os avvisi e fogli a mano italianos, os ocasionelles e relations franceses e os Zeitungen e Berichte alemães, a relaçam portuguesa e a relacion espanhola, desde suas expressóes quinhentistas, preservariam, conforme esses autores, "critérios de noticeabilidade" discerníveis, como a negatividade, a preferência pela novidade e pelo insólito, a representação das práticas e do ideário das elites como modelos socioculturais. A relação de sucessos, enquanto objeto cultural politicamente instrumentalizável, traz vantagens sobre outros veículos, como a pintura ou o livro: é barata, atinge público mais vasto (sendo o analfabetismo contornado com a leitura em voz alta), produz efeitos imediatos, é potencialmente lucrativa e virtualmente incontrolável. ${ }^{13}$

As “relaçôes de naufrágio", prósperas até fins do século XVI, quando da máxima extensão do império luso, deixam vislumbrar a enorme relevância do gênero, tanto para a conjuntura coetânea às publicações quanto para a memória legada à posteridade. Lanciani computa a alta vendagem de best-sellers como o Naufragio que passou Jorge de Albuquerque Coelho (Lisboa, em 1601): reimprimiram-se milhares de exemplares, enquanto as tiragens médias de livros raramente ultrapassavam trezentas unidades. ${ }^{14}$ Por força de narrativas assim, Jorge, donatário de Pernambuco, se tornaria herói do panteão lusitano, com os simpáticos aos Albuquerque jurando, a partir de papéis "fidedignos", ter sido dele o cavalo em que escapara d. Sebastião da Batalha de Alcácer-Quibir (1578), semente do sebastianismo. Os adversários, no século XVII, procurarão barrar relatos albuquerqueanos como as Memorias diarias de la guerra del Brasil, alegando as "falsidades" disseminadas desde a centúria anterior. ${ }^{15}$

\section{Escrever e inventar a guerra}

A circulação, pois, das primeiras relaçôes de sucessos da "Jornada dos Vassalos", ${ }^{16}$ que recupera Salvador das mãos flamengas, se filia a longa tradição retórica e editorial. Respondia-se com esses papéis a uma premência: contra-atacar discursivamente neerlandeses, diante da enorme profusão de panfletos que, desde 1624, celebravam a captura da Bahia e enlame-

\footnotetext{
${ }^{12}$ LANCIANI, Giulia. Sucessos e naufrágios das naus portuguesas. Lisboa: Caminho, 2007. SOUSA, Jorge Pedro (Coord.). A gênese do jornalismo lusófono e as relaçôes de Manuel Severim de Faria (1626-1628). Porto: Ed. da Univ. Fernando Pessoa, 2007.

${ }^{13}$ RAULT, Didier. La información y su manipulación en las relaciones de sucesos. Encuesta sobre dos relatos de batallas navales entre españoles y holandeses (1638), op. cit., discute a impossibilidade de seu controle pelas autoridades, às quais restaria apenas o adiantar-se a compor contradiscursos.

${ }^{14}$ LANCIANI, Giulia. Sucessos e naufrágios das naus portuguesas, op. cit., p. 43.

${ }^{15}$ DUTRA, Francis A. Notas sobre a vida e morte de Jorge de Albuquerque Coelho e a tutela de seus filhos. Lisboa: Centro de Estudos Históricos Ultramarinos [Separata da rev. Studia], 1974. BOUZA ÁLVAREZ, Fernando J. Portugal no tempo dos Filipes (1580-1668), op. cit., caps. 8 e 10.

${ }^{16}$ Título da famosa relação historial publicada em 1625 e que passa a identificar a expedição restauradora. GUERREIRO, Bertolameu. Jornada dos Vassalos da Coroa de Portugal. Lisboa: por Matheus Pinheiro, 1625.
} 
avam a reputação de Felipe IV e seu valido, o conde-duque de Olivares. Cartas-testemunhos relatórios da vitória e mais papéis de potencial publicístico jorravam das tipografias batavas, traduzidas para idiomas como o inglês, o francês e o alemão, decerto com impacto sobre as cidades e tropas em luta contra os espanhóis. ${ }^{17}$

A Relation veritable de la prinse de la Baya, impressa em 1624, é uma das que contam a viagem sob o almirante Jacob Willekens, do cerco da vila e da debandada dos defensores católicos, ruim nota para a reputação de portugueses e espanhóis. O governador Diego de Mendonça Furtado entra em cena preso na cidade semideserta, ao lado de meia dúzia de oficiais que não fugiram, "a chorar pela má fé de sua gente". Os oficiais neerlandeses, sublinha a Relation veritable, apregoavam perdóes para os moradores que lhes rendessem obediência, promessa debaixo da qual muitos iam retornando a suas casas e, portanto, traindo a fidelidade a El-Rey Filipe IV. Acrescentava-se que os Estados Gerais, após capturarem preciosas cargas de açúcar, aprestavam nova frota para tornar a Bahia inexpugnável. ${ }^{18}$

Descrições geográficas sobrelevavam a importância e a riqueza da capital capturada. Representava-se nos "mapas-notícias” e nas gazetas neerlandesas um Brasil edênico, em vias de ser perdido pelos papistas espanhóis, para sempre. Nos meses seguintes, o afluxo de relaçóes batavas não cessaria, investindo a WIC na manutenção do entusiasmo público com o empreendimento. ${ }^{19}$ Em 1624-1625, os flamengos amargaram revezes dos insurretos que, do Recôncavo, faziam-lhes escaramuças. Enquanto não chegavam boas novas, circularam nos Países Baixos e na França "relaçóes falsas", imaginando combates ultramarinos apenas tardiamente desmentidos, no lento ritmo das comunicações da época. Relaçôes fictícias, corriqueiras desde pelo menos o século XVI, constituíam filão editorial próprio. Para além dos lucros da vendagem, haveria conveniência política em fazer vista grossa a manchetes que alardeassem vitórias e mantivessem elevado o apoio ao esforço bélico. Grandes batalhas, como o confronto entre a Invencível Armada e a esquadra inglesa (1588), antes de serem conhecidas em seu resultado, foram falseadas por autores e editores inescrupulosos. ${ }^{20}$

Tais relações falsas terão sido impressas nos Países Baixos, na França e nas cidades espanholas e lusitanas, sobretudo no período 1624-1625. Com efeito, é também por meio de suas mentiras que a historicização do conflito principia. A história de uma guerra é também

\footnotetext{
${ }^{17}$ Sobre o impacto do "Brasil Holandês" na imprensa de Amsterdam, VAN GROESEN, Michiel. Amsterdam's Atlantic: Print Culture and the Making of Dutch Brasil. Filadélfia: University of Pennsylvania Press, 2017.

18 "Se plaignants de la mauvaise foy de leurs gens". ANÔNIMO, Relation veritable de la prinse de la Baya de todos los santos, \& de la ville de S. Sauueur au Brasil par la flotte hollandoie. Sem colofão, 1624, p. 10.

${ }^{19}$ VAN GROESEN, Michiel. Amsterdam's Atlantic: Print Culture and the Making of Dutch Brasil, op. cit., p. 44-45, 52 e passim.

${ }^{20}$ PEREIRA, Ana M. Alejandro Farnese en las relaciones de sucesos españolas. In: CARVALHO, José Adriano de Freitas (Dir.). D. Maria de Portugal: princesa de Parma (1538-1577) e o seu tempo. Porto: Inst. de Cultura Portuguesa, 1999. p. 102. MELLO, Evaldo Cabral de. O negócio do Brasil: Portugal, os Países Baixos e o Nordeste (1641-1669), op. cit., p. 103-104, 107 aponta que a WIC e a embaixada lusa financiavam em Haia panfletos, na disputa pelo Brasil Holandês.
} 
a história da construção de sua narrativa e, nesse sentido, as falsidades que sobre elas se disseram são valiosíssimas. Tal esforço de falsificação é revelador do clima das cidades europeias perante aquele conflito ultramarino e das oportunidades que pô-lo em papel franqueavam. Salvaguardada a distância ginzburguiana ${ }^{21}$ entre os que, naquela ocasiāo, fabricaram fatos e os que os relataram com esforços de fidelidade, o conteúdo das relaçóes falsas e a cretinice de seus autores são de interesse historiográfico. Através da invenção ou do relato, a todos se impunha a urgência de lançar seus papéis na praça, a fim de responder ao "bombardeio" das narrativas estrangeiras, difundindo notícias que coincidissem com as esperanças das populações e autoridades à espera de boas novas das campanhas distantes.

Antes que se conhecesse o resultado da Jornada dos Vassalos, publica-se em francês o panfleto La defaite navale, tradução, alega seu frontispício, de algum original neerlandês hoje desconhecido, relatando suposta vitória flamenga sobre a esquadra de d. Fadrique de Toledo, após longa refrega na qual teriam perecido 3 mil luso-castelhanos.

Que após uma furiosa bateria que durou quinze dias consecutivamente, os espanhóis e portugueses se retiraram e fugiram, tendo perdido mais de 3 mil homens, e entre eles mais de mil dos mais nobres e notáveis de todo Portugal. ${ }^{22}$

Derrota vexaminosa, perda irreparável... tudo falso! Também editores ibéricos procuraram lucrar com os anseios por notícias: em 10 de maio de 1625, redige-se e depois se publica em Sevilha uma Carta cierta y verdadera que vino a un cavallero desta ciudad, "noticiando" a reconquista de Salvador por d. Fadrique de Toledo e a execução de 800 neerlandeses. ${ }^{23}$ Ora, uma vez que a cidade fora rendida a 1ำ de maio, seria impossível saber-se do evento com só nove dias de intervalo (a viagem até Portugal durava cerca de seis semanas). Relação falsa. $\mathrm{O}$ anônimo autor não comunica, adivinha o desfecho da Jornada, fabricando detalhes da expedição. A malha censória, perante a astúcia desses sujeitos, revela conivência ou incompetência.

Não só perante eles: falsas ou verídicas, a maioria das relaçôes transita à margem da lei e se acha na mesma contingência de escapar à vigilância dos órgãos censores. Exceto em casos pontuais, os panfletos não apóem nos frontispícios as licenças exigidas em Portugal e Espanha. ${ }^{24}$ Nem convinha pedi-las. Tão logo aportam os informes da esquadra de d. Fadri-

\footnotetext{
${ }^{21}$ A partir do debate epistemológico Ginzburg-White, sintetizado em GINZBURG, Carlo. Relaçóes de força: história, retórica, prova. São Paulo: Companhia das Letras, 2002.

22 "Qu’apres une furieuse batterie qui dura quinze iours consecutiuement, les Espagnols \& Portugais se sont retirez $\&$ ont pris la fuitte ayant perdu plus de trois mil hommes, $\&$ entre iceux plus de mil de plus nobles $\&$ remarquable de tout le Portugal". ANÔNIMO. La defaite navale de trois mil, tant Espagnols que Portugais, mis \& taillez en pieces par les Hollandois, à la Baya de Todos los Sanctos. Traduite de Flamand en François. Paris: por Jean Martin, 1625, p. 7 (tradução livre).

${ }^{23}$ ANÔNIMO. Carta cierta y verdadera que vino a un cavallero desta ciudad.... Sevilha: por Juan de Cabrera, 1625.

${ }^{24}$ MARTINS, Maria T. E. Payan. A censura literária em Portugal nos séculos XVII e XVIII. Lisboa: Fundação Calouste Gulbenkian, 2005. VARELA, Laura Beck. Literatura jurídica y censura: fortuna de Vinnius en España. Valencia: Tirant, 2013. p. 293-298.
} 
que, em fins de junho de 1625, testemunhos de soldados, religiosos e burocratas entram a circular, alardeando a reconquista de Salvador. Esperar a tardança de meses (ou anos) pelas permissóes previstas na lei, diante da notícia "quente", seria vão. Os editores, assim, quase sempre preferem arriscar-se na ilegalidade, aliás sem receio, porque mais de uma relação clandestina dá o endereço onde os interessados poderiam adquiri-las. ${ }^{25}$

Dias após a rendição de Salvador, redigiram-se depoimentos que apareceram nas cidades ibéricas a partir de julho e agosto. ${ }^{26}$ Alguns, por causa de seu modelo epistolar, estão datados. Uma das primeiras é a Relacion de la iornada del Brasil, de 8 de maio de 1625, de autoria do escrivão-mor da armada castelhana, Bartomolé Rodriguez de Burgos, publicada em Cádiz, sem licenças. ${ }^{27} \mathrm{O}$ general das armadas, d. Fadrique de Toledo, redige relatório "oficial”, impresso em Sevilha, com as devidas licenças. ${ }^{28}$ Também os portugueses publicaram a nova: uma Relaçam verdadeira de todo o succedido na Restauração da Bahia, datada de 15 de maio e que liquidava as taxas de impressão já em 12 de julho, imprime-se em Lisboa, no Porto e em Évora. ${ }^{29}$ Algumas há que não alcançaram os prelos, como os Capítulos da relação, de $\mathrm{d}$. Jeronimo de Ataíde, preservada em manuscrito na Biblioteca da Ajuda. ${ }^{30}$

Tais relações elaborarão a base narrativa a partir da qual a Guerra Holandesa entrará a ser historiada: obras posteriores, tratando desses episódios, fazem referências às relaçóes de então e depois. ${ }^{31}$ Seu valor historiográfico é, por isso, fundante. Trata-se de discurso formulado sob os auspícios da Coroa e da nobreza partícipe da Jornada, cuja vigilância busca silenciar vozes dissonantes, chegando a negar licenças a versóes heterodoxas do evento. ${ }^{32}$ A representação contida nas relaçóes publicadas compóe, em seu conjunto, uma aventura: expedição posta a árduas provas, em mar e terra, e que triunfa na defesa dos desígnios de

\footnotetext{
${ }^{25}$ ANÔNIMO, Carta cierta, y verdadera y verdadera que vino a un cavallero desta ciudad..., op. cit. Apesar da narração falsa que traz e da óbvia ausência de licenças, avisa ter o impressor loja "frontero del Correo Mayor" de Sevilha.

${ }^{26}$ CAMENIETZKI, Carlos Ziller; PASTORE, G. Grassia. 1625, o fogo e a tinta: a batalha de Salvador nos relatos de guerra. Topoi, Rio de Janeiro: v. 6, n. 11, p. 261-288, jul./dez. 2005.

${ }^{27}$ BURGOS, Bartolomé Rodriguez de. Relacion de la iornada del Brasil, escrita a Ivan de Castro Escrivano Publico de Cadiz, por Bartolome Rodriguez de Burgos Escrivano mayor de la Armada. Cádiz: por Juan de Borja, 1625. ${ }^{28}$ OSÓRIO, d. Fadrique de Toledo. Relacion de la carta que embio a su Magestad el Señor don Fadrique de Toledo, general de las Armadas, y poderoso exercito, que fue al Brasil. Sevilha: por Simon Faxardo, 1625.

${ }^{29}$ ANÔNIMO. Relaçam verdadeira de tudo o succedido na Restauração da Bahia de todos os Sanctos. Lisboa: por Pedro Craesbeek, 1625.

${ }^{30}$ MAGALHÃES, Pablo A. I. Equus rusus: a Igreja Católica e as Guerras Neerlandesas na Bahia (1624-1654), op. cit., v. III, anexo III.

${ }^{31}$ A Jornada dos Vassalos, de B. Guerreiro, as Memorias diarias, de Duarte de Albuquerque Coelho, a Historia de don Felipe IIII, de Cespedes y Meneses e outros buscarão informaçóes em relações do período. CLEMENTINO, Kleber. Politica e historiografia nas narrativas lusocastelhanas seiscentistas da Guerra Holandesa, op. cit. ${ }^{32}$ SCHWARTZ, Stuart. B. The Voyage of the Vassals: Royal Power, noble obligations and merchant capital before the Portuguese restoration of independence (1624-1640), op. cit., aludirá à ação de bloqueio do Conselho de Estado madrileno. O caso clássico é a proscrição do relato do almirante português d. Manuel de Menezes, Recuperaçáo da cidade de Salvador, que apontava desinteligências no oficialato e apenas seria publicado no século XIX.
} 
Deus e do rei. Operam esses pioneiros a condensação dos acontecimentos de seis meses (desde a partida dos portos da Europa, em fins de 1624, até a rendição da praça, em maio) no espaço de algumas páginas, submetendo o real a criteriosa seleção dos eventos e personagens "dignos" de registro. No processo despontam os primeiros heróis, lances trágicos ou memoráveis, baixas lastimosas e a festejada reconquista da cidade. A linguagem é direta, despida de adornos, carregando no horroroso e sangrento, como em: "posto se náo especifica as baterias de cada dia saibam, que num e noutro quartel todos os dias haviam [sic] mortos e feridos sem pernas e braços. ${ }^{33 "}$

Não obstante se saiba, por meio de outras fontes, de querelas no alto comando da expedição, o tom das relações é de harmonia no oficialato. O cerco é bem-sucedido pela perícia e resolução de d. Fadrique de Toledo, d. Juan Fajardo, d. Manuel de Meneses e mais oficiais, nomes celebrados nos panfletos portugueses e castelhanos de 1625 , cujas façanhas liquidam os sitiados. Sufocados por essa calibrada máquina bélica, os soldados da WIC são pintados de início arrogantes, depois confusos, depois desesperados, amotinando-se ao antever a queda iminente.

Vendo que nossa artilharia havia descavalgado a sua, e tendo entre eles muitas dissenções, pelas diferentes naçóes que se haviam confederado pelos Estados rebeldes para esta ocasião, entre quem é uso muitas rebelióes e motins, de que procedeu ferir e prender ao Coronel que os governava [...]; criaram outro Coronel, e trataram de render-se. ${ }^{34}$

Coesão católica versus desordem herética. Tanto em Portugal quanto em Castela, as aristocracias assumem a direção dessa primeira historicização da guerra, entendendo-a como matéria de Estado. Rault demonstra a labuta do conde-duque de Olivares, alguns anos mais tarde, para, na impossibilidade de proibir a circulação de relações, muitas vezes antecipar-se a elas e pautar a construçáo da narrativa das guerras espanholas do período, por intermédio de escritores a serviço da corte. ${ }^{35}$ No Annus Mirabilis de 1625 , ao mesmo tempo em que Filipe IV obtinha triunfos em Flandres e na região alpina da Valtelina, o império exploraria o potencial publicístico de seus sucessos, no teatro, na iconografia e nas casas impressoras. ${ }^{36}$

\footnotetext{
${ }^{33}$ ANÔNIMO, Relaçam verdadeira de todo o sucedido na restauração da Bahia de todos os Sanctos, op. cit., sem paginação.

34 "Viẽdo que nuestra artilleria les avia desencavalgado la suya, y teniendo entre ellos muchas dissensiones, por las differentes naciones que se avian confederado por los Estados rebeldes para esta ocasion entre quien es uvo [sic por uso] muchos rebeliones y motines, de que procedio herir y prender a el Coronel que los governava [...]; criaron otro Coronel, y trataron de rendirse". AVEDAÑO Y VILELA, Francisco de. Relacion del viaie, y sucesso de la Armada que por mandado de su Magestad partio ao Brasil. Sevilha: por Francisco de Lyra, 1625, não paginado.

${ }^{35}$ RAULT, Didier. La información y su manipulación en las relaciones de sucesos. Encuesta sobre dos relatos de batallas navales entre españoles y holandeses (1638), op. cit.

${ }^{36}$ ELLIOTT, John. El conde-duque de Olivares: el político en una época de decadencia. Barcelona: Crítica, 2010.
} 


\section{Silêncio peninsular, eloquência ultramarina}

A guerra, como se sabe, prossegue ainda em 1625, com combates na Baía da Traiçáo, na Paraíba, já em agosto daquele ano, ataques de Piet Heyn na costa baiana (1626-1627) e na grande esquadra que assaltou Pernambuco (1630). No primeiro caso, estavam as nobrezas portuguesa e espanhola à frente da ação militar, o que explica a enorme reverberação da recuperaçáo da Bahia na Europa; nos demais, governadores e capitães dos rincóes ultramarinos comandaram a luta, o que explica o relativo silêncio acerca dos eventos bélicos após 1625. Não é preciso dizer qual desses grupos teria mais fácil acesso às tipografias, maior clientela de "letrados" prontos a adornar suas façanhas e mais largos recursos para publicizá-las. Nem é por acaso que, concluída a Jornada dos Vassalos, o ritmo das relaçóes entra em marcha lenta pelos anos seguintes, aparecendo apenas escassamente, embora debaixo dessa escassez resida uma importante virada na construção da narrativa da guerra.

$\mathrm{Na}$ história da reconquista da Bahia contada pelas relaçóes de sucessos, ouve-se a voz de grupos aristocráticos que patrocinaram sua escrita. Daí consistir o enredo na chegada das novas à Europa, o apresto da armada, a travessia do Oceano e a salvação do Brasil. Fabrica-se epopeia cruzadística deleitosa de se ler e repetir. A resistência no Recôncavo, cortando o acesso neerlandês ao interior açucareiro, se converte em episódio menor. Não que não se tenham redigido testemunhos dessa resistência, mas estes terão de aguardar os séculos XIX e XX para, afinal, virem à luz. ${ }^{37}$

Isto muda após a invasão de Pernambuco. Não se repete nenhuma massiva mobilização militar, senão magros e tardos socorros. O advento dessa nova fase de reveses alterará as linhas da historicização da guerra, porque, afastando-se as casas nobres dos campos de batalha americanos, abre-se espaço a novas vozes historiantes, provenientes das elites atuantes no ultramar. Sem os mesmos recursos materiais e intelectuais de que dispunha a aristocracia europeia para dar fama a suas açóes, chefes em Pernambuco, na Paraíba, em Luanda e alhures perceberam, não obstante, a vantagem de escrever e imprimir. Visibilizar-se e heroicizar-se foi tática valiosa não só para quem já era nobre, mas para os que aspiraram aos canais de nobilitação e às recompensas por façanhas guerreiras. ${ }^{38}$.

No século XVII, inexistindo em Portugal ou Espanha instituiçôes jornalísticas autônomas, a comunicação social obedece a uma lógica distinta da contemporaneidade. Equivo-

\footnotetext{
${ }^{37}$ Por exemplo, TEENSMA, B. N. (Ed.). Brasil holandês: dois manuscritos portugueses sobre a conquista neerlandesa (1624) e a reconquista lusoespanhola (1625) de Salvador da Bahia no Brasil. Rio de Janeiro: Index, 1999, bem como os relatos encontrados por Pablo Magalhães, como os Capitulos da Relação já citados. ${ }^{38}$ LEITE, Jorge Miranda. $O$ dito e o feito: heróis exemplares nos relatos de guerra na Restauraçáo pernambucana (1630-1654). Dissertação (Mestrado em História) — Programa de Pós-graduação, Universidade Federal Fluminense, Niterói,, 2009. AROUCHA, Marcone Zimmerle. Serviço e nobilitaçâo: a dinastia bragantina e as concessóes de foro de fidalgo no Atlântico Sul (1640-1680). Dissertação (Mestrado em História) — Universidade Federal de Pernambuco, Recife, 2015.
} 
cam-se Sousa e Lanciani: há descontinuidade entre este "protoperiodismo" e o jornalismo posterior. Na Alta Modernidade, não se reporta, de ordinário, o que se avalia socialmente relevante, mas o que se prevê politicamente recompensável, pois são facçóes e atores políticos que patrocinam os relatos. Mesmo na imprensa mais consolidada de Amsterdã, estudada por Van Groesen, atende-se a esse jogo de poderes nos ritmos e temas das publicaçóes. ${ }^{39}$ Há, sim, os que lucram com as relações de sucessos, todavia, o aspecto econômico é ainda secundário. Via de regra, não é a recompensa financeira nem a "noticeabilidade" que primariamente impulsionam as impressóes; se fossem, as quedas de Salvador em 1624 e a de Olinda em 1630 teriam legado vasto repertório. Um desastre militar, ainda que alvo de ampla curiosidade, bem poderia ver-se abafado - exceto se a grupos prejudicados conviesse vir a público justificar-se. Os atos de relatar e historiar, no Seiscentos, são intrinsecamente políticos. Grosso modo, legou-se para o futuro a história que determinados agentes políticos quiseram, ou precisaram, contar.

Isto se verifica na historicização da guerra após 1630. Tomada Olinda pelos exércitos da WIC em velocidade vergonhosa, ameaçado o Recife e o rico interior açucareiro, a quem importava dar parte daqueles malogros? Não aos "vassalos" vencedores de 1625, certamente. Havia, porém, facção interessadíssima em explicar a derrota: a família donatarial de Pernambuco, os Albuquerque, acusados de negligência na Europa. É o que motiva, ainda em 1630, a publicação da Relaçam verdadeira, e breve da tomada da villa de Olinda. Primeiro (de muitos) texto albuquerqueano da Guerra Holandesa, sublinhando o sacrifício do general Matias de Albuquerque e de seus capitães.

O autor, "religioso de muita autoridade" e testemunha ocular, espanta-se com a superioridade dos "petrechos, e invenções de guerra" batavos: "peças ligeiríssimas", capazes de disparar projéteis pesados, e revestidas de tão bons couros que "tiram dez, e doze tiros sem se queimarem, e [...] fazem o mesmo efeito, que se foram de bronze". Surpreendia-o também o engenho com que transportavam seus canhões, com versátil maquinário. Todo o discurso persuade o leitor de ser impossível a defesa, apesar da energia com que agia o "superintendente na guerra" Matias de Albuquerque: de Pau Amarelo ao Recife, "a todos os assaltos se achou presente, e correndo a uma, e outra parte, como destro, e valoroso capitáo", dando ordens, cavalgando entre balas inimigas, enchendo cartuchos de pólvora com as próprias mãos como mero "soldado particular, e ainda [...] artilheiro". Tudo em vão. Depois do desembarque,

Foram [os neerlandeses] tomar o passo do Rio Tapado, aonde puderam os nossos fazer muito mal ao inimigo, se tiveram perdido o medo aos pelouros, que sobre eles choviam; porém o medo ia de cada vez crescendo, e a gente diminuindo-se, e os pareceres variando-se. ${ }^{40}$

\footnotetext{
${ }^{39}$ VAN GROESEN, Michiel. Amsterdam's Atlantic: Print Culture and the Making of Dutch Brasil, op. cit. ${ }^{40}$ ANÔNIMO. Relaçam verdadeira, e breve da tomada da villa de Olinda, e lugar do Recife na costa do Brazil pellos rebeldes de Olanda. Lisboa: por Mathias Rodrigues, 1630. p. A-A2.
} 
Desenhado o cenário adverso, resta ao autor justificar a derrota, inculpando-a ao pouco empenho da "gente de guarniçáo" e dos nobres locais. Albuquerque, lê-se, teima em defender Olinda do assalto batavo, mas os da terra o reprovam, "havendo-o por sabida temeridade"; desguarneceram os fortes de Recife, para onde se haviam retirado, e "desmaiaram de sorte, que [...] cada um não tratava mais, que [...] pôr-se em salvo". Matias, insistindo na resistência suicida, enquanto os que o rodeiam o abandonam, é figurado como este trágico comandante traído, forcejando por reter os homens em seus postos, mas debalde, de maneira que só lhe restará incendiar os armazéns do porto, para evitar sua lucrativa captura pela WIC, atitude "avaliada por de grande capitáo". 41

Vai-se assistindo à apariçáo de inusitado rol de guerreiros ainda desconhecidos do público luso-castelhano. Na Relaçam verdadeira brilham rebentos de famílias que construíam sua fortuna no ultramar, mantinham ali clientelas e agora almejavam à "fama”. Os Albuquerque em primeiro plano, porém não só eles: capitães como André Temudo e o padre-soldado Manoel de Morais despontam obrando façanhas memoráveis, morrendo bravamente ou mobilizando índios para o desagravo da honra de el-rei. A visibilização dos chefes ultramarinos implicava heroicizar também seus melhores auxiliares, em cujo elogio as relaçóes se esmeram. Tem-se, portanto, manifestaçôes não de indivíduos, mas sobretudo de grupos políticos encastelados nos domínios em que a Guerra Holandesa se ia travando.

Deslocar-se a voz historiante para o Brasil introduz não só novos protagonistas, mas também linguagem nova, uma forma distinta de dizer a guerra, e alteraçôes nos suportes materiais dos textos. Sem grandes expediçóes, importava amplificar vitórias de menor magnitude: o rechaço a cercos, as marchas forçadas, as escaramuças da guerrilha cotidiana. As relações sobre a Guerra Holandesa dos anos 1630 e 1640 circularão, em sua maioria, manuscritas, sem o alcance dos produtos tipográficos. ${ }^{42}$ Esse recuo do impresso, como dito, não decorre de critérios de noticeabilidade, mas do recuo da elite peninsular no controle dos canais da cultura escrita. Envolvidos com os conflitos de Flandres e da Itália, a longínqua guerra no Atlântico lhes terá menor apelo. Deve-se, pois, considerar a publicação das relaçôes de sucessos da elite ultramarina como demonstração dessa força política nova, aproveitando o espaço aberto pelo desinteresse da aristocracia; ação que ambicionava fixar uma nobreza neófita, forjada no serviço militar, concorrente daquela que triunfara em 1625.

Também os Albuquerque da Paraíba ${ }^{43}$ chefiados pelo capitão-mor Antônio de Albuquerque, depois de resistirem à investida da WIC sobre os fortes da vila de Filipeia, em

\footnotetext{
${ }^{41}$ Ibidem, p. A2v-A3v.

${ }^{42}$ CLEMENTINO, Kleber. Politica e historiografia nas narrativas lusocastelhanas seiscentistas da Guerra Holandesa, op. cit., cap. 2.

${ }^{43}$ Ramo colateral descendente não do primeiro donatário de Pernambuco, Duarte Coelho (como o general Matias e seu irmáo Duarte), mas de seu genro, Jerônimo de Albuquerque, pai de Jerônimo de Albuquerque "o Maranhão" (1548-1618), conquistador da capitania maranhense, e avós de Antônio de Albuquerque Maranhão, capitão-mor da Paraíba entre 1622 e 1635. Ver ALMEIDA, Horácio de. História da Paraíba. João Pessoa: Imprensa Universitária, 1966. t. I.
} 
dezembro de 1631, decidem levar ao prelo sua façanha. Encarregaram frei Paulo do Rosário, abade geral da província beneditina no Brasil, de redigir a Relaçam breve, e verdadeira da memoravel victoria. ${ }^{44}$ Rosário, jurando não narrar "com ânimo de lisonjear", outra coisa não fará, mitificando Antônio de Albuquerque, seus parentes e seus capitães. Mostra-os lutando na Paraíba e em Pernambuco, gastando de sua fazenda nos reparos das fortalezas, resolvidos a morrer pelo rei e pela fé. Antônio - cuja representação lança máo de artimanhas análogas às da Relaçam verdadeira de 1630 — é comparado a chefes veterotestamentários e ilustres lusitanos. Se as escrituras, diz Rosário, louvam Abraão por suas vitórias, fazem-no pela prontidão com que agira,

Porque entre o ouvir na nova, e fazer aprestos de guerra, não houve meio algum. Não merece menos gavos [sic] o vigilante Capitão Antonio de Albuquerque, o qual não sei se por imitar ao santo Patriarca [Abraão], ou se por seguir o exemplo da pressa com que o grande Afonso de Albuquerque, de gloriosa memória, remediou todos os cercos... ${ }^{45}$

Os Albuquerque, em especial sua contraparte de Pernambuco, registrarão o cotidiano da luta em manuscritos, fontes para a futura escrita das Memorias diarias do donatário Duarte de Albuquerque Coelho, publicadas em 1654 - obra seminal para a construção da narratio seiscentista da guerra, revisitada por leitores-autores do século XVIII como Barbosa Machado e frei Jaboatáo, e por Varnhagen, no século XIX, que a listava entre os relatos mais confiáveis. ${ }^{46}$ Por outro lado, episódios como a marcha comandada pelo mestre de campo Luís Barbalho (1640), do Rio Grande do Norte à Bahia, darão azo a impressos, ao que tudo indica encomendados por oficiais na campanha. ${ }^{47}$ Acaso o fracasso da armada do conde da Torre (1638-1640) terá contribuído para alienar ainda mais a nobreza peninsular e dar vazão à ideia de entrega do território, já então aventada ${ }^{48}$.

No caso do cerco nassoviano de 1638 à Bahia, publicam-se alguns panfletos, entre os quais a Relacion de la vitoria que alcanzaron las Armas Catolicas. ${ }^{49}$ Capitães despachados a

\footnotetext{
${ }^{44}$ ROSÁRIO, Paulo do. Relaçam breve, e verdadeira da memoravel victoria que ouve o capitão mor da capitania da Paraiva Antonio de Albuquerque. Lisboa: por Jorge Rodrigues, 1632.

${ }^{45}$ Ibidem, p. 3v. A semelhança dos títulos e o fato de serem ambos os autores religiosos "de autoridade" faz desconfiar se não seria Rosário também o autor da relação de 1630.

${ }^{46}$ Alguns relatos dos anos 1630 estão preservados na Biblioteca Nacional de Portugal, Cód. 1555, e no Archivo General de Simancas, Guerra y Marina, legajo 1325. Para a presença deles na relação das Memorias diarias ver CLEMENTINO, Kleber. Politica e historiografia nas narrativas lusocastelhanas seiscentistas da Guerra Holandesa, op. cit., p. 60-61, 165. MELLO, Evaldo Cabral de. Olinda restaurada: guerra e açúcar no Nordeste, 1630-1654. Sáo Paulo: Editora 34, 2007, especialmente p. 26-43.

${ }^{47}$ ANÔNIMO. Sucessos de la armada que fue al Brasil, y el largo viaje que tuvieron por tierra.... Sevilha: por Nicolas Rodriguez, 1640.

${ }^{48}$ MELLO, Evaldo Cabral de. O negócio do Brasil: Portugal, os Países Baixos e o Nordeste (1641-1669), op. cit. ${ }^{49}$ ANÔNIMO. Relacion de la vitoria que alcanzaron las armas Catolicas en la Baia de Todos Santos, contra Olandeses, que fueron a sitiar aquella Plaça, en 14. de junio (sic) de 1638. Madri: Francisco Martinez,
} 
Madri, sedentos de mercês por suas açóes, teriam boas razóes para fazer seus nomes afamados, sobretudo em relato favorecido pela Coroa. Reveladoramente, a Relacion atribui notável protagonismo ao oficialato responsável pelo rechaço às forças da WIC: o conde de Bagnuolo, castigado em outros escritos como incompetente e traidor, surge aqui prudente, ágil; Sebastião de Souto ("Viriato da nossa idade, terror do holandês, lustre do lusitano nome"50), Luís Barbalho, Pedro Cadena de Vilhasanti, Filipe Camarão, o próprio Duarte de Albuquerque, também fustigado em outros escritos, têm suas façanhas destacadas na obra, louvados por sua "fineza espanhola". Veem-se aclamados como merecedores de renome imortal: "o valor destes Generais, posto à vista de todos naquele teatro de Belona, de tal sorte alentou aos soldados, que desde logo se teve por feliz prognóstico da vitória que conseguiram". 51 O encômio dos feitos do grupo dá o tom da Relacion de la vitoria, como declaraçáo desta articulação de interesses que se faz ouvir em Madri, taticamente evocando a retórica oficial do olivarismo, da reunião de povos católicos que defendiam a fé contra hereges luteranos (sem jamais mencionar as dissensões internas do Império Habsburgo, já então profundas). Os afagos dirigidos a Diogo Soares, secretário de Estado em Portugal, ecoam a bajulação de quem procura apoios e prêmios.

\section{A Insurreição Pernambucana nas relações de sucessos}

A Restauração Portuguesa (1640), metamorfoseando a conjuntura linguística em que a política passava a ser dizível, ${ }^{52}$ terá impacto limitado na escrita de relaçóes de sucesso da Guerra Holandesa. O ritmo das impressóes segue lento e, mesmo depois da eclosão da Insurreição Pernambucana, em 1645, o investimento na publicação de narrativas será errático. Triunfos como as Batalhas das Tabocas e de Casa Forte, em agosto de 1645, primeiras vitórias frente aos exércitos neerlandeses em quase uma década, serão lidos em letra de forma tardiamente, e não em folhas avulsas, mas já em livros. As vitórias dos Guararapes (16481649) e a capitulação do Recife (1654) até darão azo a panfletos, porém agora reproduzindo o discurso da Coroa, desejosa de controlar a narrativa dos eventos. Nos anos finais, desloca-se outra vez a voz historiante a patrocinar relaçóes, de volta do ultramar para a Europa.

1638. Magalhães propóe que esta Relacion seria encomenda do próprio conde-duque, no interior do projeto de Unión de Armas, destinado a aumentar a subordinação de Portugal à Coroa castelhana. Discordamos, parecendo-nos antes narrativa patrocinada pelo grupo que viaja a Madri para anunciar a boa nova. MAGALHÃES, Pablo A. I. A Relacion de la victoria que alcanzaron las Armas Catolicas en la Baia de Todos Santos, do Bispo D. Juan de Palafox y Mendonza. Topoi, v. 12, n. 23, p. 47, jul./dez. 2011.

50 "Viriato de nuestra edad, terror del Olandes, lustra del lusitano nombre". ANÔNIMO, Relacion de la vitória que alcanzaron las armas Catolicas en la Baia de Todos Santos, contra Olandeses, que fueron a sitiar aquella Plaça, en 14. de junio (sic) de 1638, op. cit., p. 5.

51 "El valor destos Generales puesto a la vista de todos en aquel teatro de Belona, de tal suerte alentò a los soldados, que desde luego se tuvo por feliz pronostico de la vitoria que consiguieron”. Ibidem, p. 4v.

${ }^{52}$ Cf. POCOCK, John G. Linguagens do ideário político. São Paulo: Edusp, 2013. 
Ora, vivia-se o imbróglio diplomático resultante da Restauração Portuguesa e da Insurreiçáo Pernambucana. Lusitanos e neerlandeses, apesar da trégua assinada em 1641, mantiveram notório estado de beligerância, marcados por pontuais entreveros na Índia, em Angola e no Maranhão..$^{53}$ Anelando pelo cessar-fogo, dada sua debilidade financeira e militar, a Portugal não convinha testar a paciência dos Estados Gerais. Os incêndios de canaviais e razias pelo interior de Pernambuco não poderiam ser ligados ao governo geral na Bahia ou ao Paço; a Insurreição liderada por Fernandes Vieira deveria ser posta na conta da insatisfaçáo local, não obstante cartas apreendidas pelos batavos comprovassem o beneplácito régio ao motim. De modo a "negar as aparências e disfarçar as evidências", importava acusar os insurretos de rebeldia, o que prejudicava eventuais intençôes de publicizar a luta. Apesar das "vitórias milagrosas" no Brasil, emergia perigosa ameaça à independência lusa. A retaliação batava poderia vir na forma de golpe que tomasse a Bahia ou, pior, de aliança antilusa com a Espanha para a invasão do Reino. Os censores lisboetas não quererão saber de papéis dos sucessos do Brasil, voltando a atenção para a Guerra de Restauração.

Náo por acaso, uma das mais antigas relaçóes impressas sobre a Insurreiçáo vem à luz, sem licenças, depois de 1646: Successo della guerra de Portugueses levantados em Pernambuco. O impresso sequer traz colofấo, o que sugere a atmosfera censória em Lisboa e o receio dos editores. Apesar do texto em português, o título da relação está gravado em espanhol, o que tanto pode ser manobra diversionista "para holandês ver", como indicar tipógrafo estrangeiro. Trata-se não de relato por pena contratada (como se haviam apressado a fazer os Albuquerque, nos primeiros anos 1630, ou os capitães após o cerco nassoviano de 1638), mas um conjunto de cartas, atribuídas a André Vidal de Negreiros, Martim Soares Moreno, Fernandes Vieira e às autoridades da WIC no Recife, papéis saídos da chancelaria de Salvador, como indica seu último parágrafo. ${ }^{54}$

Sem embargo da origem clandestina, a Successo della guerra veicula a versão oficial da Coroa, aliás arguida em Haia: o governador geral Antonio Telles da Silva ordenava o retorno de Negreiros e Moreno à Bahia, mas "o Povo", taxado de desatinado, alegava náo reconhecer "mais que a Deus, e ao primeiro príncipe católico que os acudisse". A hipótese de evocar "príncipe católico" - o rei francês ou o espanhol — diante da inércia dos Bragança, reaparecerá adiante, por seu valor de leitmotiv em favor dos insurretos e como pretexto diplomático para d. João IV os socorrer. Elegia aquele povo, continua o relato, "Ioaon Francisco [sic] Vieira" por seu líder e este se recusava a abandonar o povo em desespero e insubordinado ("andam táo soltos e demasiados no falar, que ninguém se atreve a reprovar-lhes estas suas açôes"). Com o recrudescimento das "inumanidades feras, e bárbaras" dos batavos, e frisan-

\footnotetext{
${ }^{53}$ MELLO, Evaldo Cabral de. O negócio do Brasil: Portugal, os Países Baixos e o Nordeste (1641-1669), op. cit., cap. II.

${ }^{54}$ Transcreve-se ali a chancela do traslado das cartas, por parte de "Joaon Borges de Escovar escrivão da ouvidoria geral deste Estado", com data de outubro de 1646. ANÔNIMO, Successo della guerra de Portugueses levantados em Pernambuco contra Olandeses. Sem colofão nem data.
} 
do ser "tudo causado de v.s. não haver querido socorrer aquelas Capitanias do Norte", todos resolveram ficar e lutar. 55

A Successo della guerra se encerra com troca de cartas entre os "ministros da Companhia" e Negreiros e Moreno. Aludem os mestres de campo, ameaçadoramente, aos muitos braços à disposição dos rebeldes, os quais, "sendo menos em número tinham rebatido o poder de V. S. como foi no lugar das Tabocas". É, acaso, a primeira mençâo impressa conhecida à Batalha das Tabocas. Até esta altura (1646-1647), publicizar a guerra não convinha a Lisboa sempre pisando em ovos com os Estados Gerais - e, em Pernambuco, o "partido vieiriano", isto é, a fração da açucarocracia insurreta ligada a Fernandes Vieira, aguardava a publicação d'O valeroso Lucideno, que viria a lume em lustrosa ediçâo dos Craesbeeck. ${ }^{56}$ Até 1648 , essa versão que isentava a corte e descrevia uma rebeliáo autônoma atendeu às necessidades discursivas da corte e do ultramar. Depois o cenário mudará.

A queda de braços diplomática em Haia, sob os vaivéns das negociaçóes para o fim da Guerra dos Trinta Anos, degrada as relaçóes lusoneerlandesas, sobretudo face às inesperadas vitórias dos Guararapes e de Angola (1648). Mesmo com o medo de uma invasáo iminente do reino, a proposta da entrega da porçáo norte do Brasil para os Países Baixos, em troca da paz, submerge e o partido linha-dura da corte, encabeçado por figuras como o conde de Penaguião, impôe seu si vis pacem para bellum ao rei. ${ }^{57}$ Também em 1648, assume o comando das forças no Brasil o enviado da corte, Francisco Barreto de Menezes, destituindo o soi-disant "primeiro aclamador da liberdade", Fernandes Vieira, e seu aliado Negreiros. Acumulavam-se acusaçôes contra Vieira de "tirania" e ilicitudes, discutidas no Conselho Ultramarino em 1647. A substituição, por isso, era constrangedora e ameaçava a liberdade e a reputação dos chefes locais, o que o próprio Lucideno procurará remediar. As relaçôes impressas dos anos finais da guerra pintam os "aclamadores" como meros auxiliares de Barreto de Menezes, valentes, sim, porém atuando debaixo das asas do general.

É o caso da Relacion de la victoria que los Portugueses de Pernambuco alcançaron de los de la Compañia del Brasil en los Garerapes a 19. de Febrero de 1649., que anuncia o triunfo da segunda Batalha dos Guararapes. Ao contrário da Successo della guerra, não são cartas, mas obra de letrado, com meditaçôes sobre o valor das grandes façanhas e a obrigaçáo de divulgá-las. As açóes que conduziram à vitória de 1649 são apresentadas como imorredouras, firmando-se linhas de representação encontradas nas obras históricas publicadas depois, no reinado de d. Pedro II.

\footnotetext{
${ }^{55}$ Ibidem, p. 2-5.

${ }^{56}$ CALADO, Manuel. O valeroso Lucideno, e Triumpho da Liberdade. Primeira parte. Lisboa: por Paulo Craesbeeck, 1648.

${ }^{57}$ MELLO, Evaldo Cabral de. O negócio do Brasil: Portugal, os Países Baixos e o Nordeste (1641-1669), op. cit., cap. IV.
} 
As açóes grandes são mais para admiradas, que repetidas; porque aquilo que têm de maiores, faz [com] que não seja possível referir como elas são. É difícil escrever o engenho com a pena, o que o valor obra com as armas: um forma seus caracteres com a tinta, e outras os imprimem com o sangue. Mas esta dificuldade não é poderosa, para que a verdade, como alma dos sucessos, deixe de publicar o obrado, já para o exemplo, já para o aplauso, pois tanto e ainda mais nos incitam as histórias presentes, que as passadas..$^{58}$

O colofão declara-a "traduzida do alemão" e impressa em Viena, o que soa estranho: o panfleto não apóe licenças e o incomum rigor com que estão grafados os nomes ibéricos faz desconfiar desse tão zeloso autor teutônico. É sabido que a publicação de textos em castelhano era recurso comum no Seiscentos luso, dada a maior penetração europeia da língua cervantina. Isto acaso indica que a publicização da Guerra Holandesa se tornava conveniente ou urgente, ${ }^{59}$ haja vista a publicação também d'O Valeroso Lucideno no ano anterior, obra ou encomendada, ou dedicada a Fernandes Vieira. Sem dúvida elogiosa para com Negreiros e Fernandes Vieira, A Relacion de la victoria que los Portugueses de Pernambuco alcançaron faz de Barreto de Menezes o único comandante-em-chefe, o que leva a suspeitar de encomenda sua ou de seus aliados. Dele emanam ordens pontualmente cumpridas, é ele que posiciona os pelotôes e guerreia em todas as partes: "basta dizer-se [de Menezes] que se lhe deve a maior parte desta vitória, pois de sua acertada disposição, valor, e diligência resultou o alcançá-la tão gloriosamente". ${ }^{60}$

Tal como desde 1630, seguirão escassas as publicações nesses anos finais, acerca da guerra no Brasil e em Angola, não obstante cartas relatassem eventos importantes. ${ }^{61}$ Acordando-se o cessar-fogo de 1654, logo sai a Relaçam diaria do sitio, e tomada da forte praça do Recife,

\footnotetext{
58 "Las acciones grandes son màs para admiradas, que para repetidas; porque aquello que tienen de mayores, haze que no puedan refirirse como ellas son. Es dificil escrivir el ingenio con la pluma, lo que el valor obra con las armas: una forma sus caracteres con la tinta, y otras los imprime con la sangre. Pero esta dificultad, no es poderosa, para que la verdad, como alma de los sucessos, dexe de publicar lo obrado, ya para el exemplo, ya para el aplauso, pues tanto, y aun màs, nos incitan las historias presentes, que las passadas". ANÔNIMO. Relacion de la victoria que los Portugueses de Pernambuco alcançaron de los de la Compañia del Brasil en los Garerapes a 19. de Febrero de 1649. Viena: (sem ind. de impressor), 1649.

${ }^{59} \mathrm{O}$ autor anônimo faz referência a relações de sucessos "inimigas", rebatendo-as tanto por dizerem falsidades (no número de oficiais mortos, por exemplo) como porque não detalhassem as circunstâncias gloriosas do sucesso. ANÔNIMO, Relacion de la victoria que los Portugueses de Pernambuco alcançaron, op. cit., p. $2 \mathrm{v}$. 60 "Basta dezirse que se le deve la mayor parte desta victoria, pues de su acertada disposicion, valor, y diligencia, resultò el alcançarse tan gloriosamente”. Ibidem, p. 9.

${ }^{61}$ A primeira Batalha dos Guararapes deu azo a missivas de Felipe Bandeira de Melo, Barreto de Menezes e Negreiros, nenhuma delas, ao que se saiba, então levadas ao prelo. Francisco de Brito Freire relatará também a rendição do Recife em fins de janeiro de 1654, preservando-se o manuscrito nos arquivos da Casa de Cadaval. RAU, Virgínia. A primeira Batalha dos Guararapes descrita por André Vidal de Negreiros. Coimbra: Coimbra Ed., 1955 (Sep. da Brasília, v. IX).
} 
pela Officina Craesbeeckiana, cedo reimpressa e traduzida para o italiano. ${ }^{62}$ Como havia muito não se fazia acerca da guerra, a rendiçáo é relatada à larga, aparecendo outros panfletos em português e uma Relacion verdadera de la recuperacion de Pernambuco, gravada em Lisboa também pela família Craesbeeck, a qual se desfecha com este inusitado desafio, em um Portugal em guerra com Espanha e Holanda:

Esta relação verdadeira do último, e maior sucesso da guerra do Brasil (táo maravilhoso, como todos os outros, com que Deus tem atestado, que é vontade sua estabelecer esta Coroa de Portugal na pessoa e sucessão do rei D. JOÁO IV nosso Senhor) escreve-a um Português em língua castelhana, para que nossos inimigos a entendam, e para que tenha muito de notória, pois tem tudo de verdadeira. ${ }^{63}$

Esforço que também terá levado à publicação da La victoire remportee par les portugais sur les holandais, tradução de relato luso hoje perdido e que reproduz a versão autorizada da capitulação. ${ }^{64}$ Nesses textos desponta a figura de Barreto de Menezes e, acima dele (embora sem se admitir sua cumplicidade), de d. Joáo IV, a presidir a recuperaçáo do Brasil. Os chefes locais só coadjuvam a ação.

Esses papéis nos reportam que, no apagar do reinado joanino e na reta final do conflito ultramarino, o centro político peninsular retomava o controle publicístico da guerra. O que não deixa de agir em desfavor das ambiçôes do partido vieiriano. Não só as vitórias dos Guararapes são atribuídas às qualidades de Barreto de Menezes; a rendição do Recife decorreria do engenho de Pero Jacques de Magalhães, almirante da armada da Companhia Geral de Comércio, e do mestre de campo general, que cerca os batavos por terra. A glória ressoava em favor de el-rei e dos generais por eles despachados, não de amotinados como Vieira ou Negreiros. Temos, de certa forma, um eco do cenário discursivo de 1625, quando à Coroa também interessava presidir os aspectos dessa historicização, em prejuízo das vozes "excêntricas", que doravante encontrariam menos oportunidades de se fazer ouvir.

\footnotetext{
${ }^{62}$ ANÔNIMO. Relaçam diaria do sitio, e tomada da forte praça do Recife. Lisboa: Officina Craesbeckiana, 1654. Barbosa Machado a atribui a Antonio Barbosa Bacellar (1610-1663), sobre quem não indica nenhuma vinda ao Brasil. Aponta-o, ao contrário, no reinado de d. João IV como lente na Universidade de Coimbra, depois mudando para Lisboa, por desavenças acadêmicas, onde é nomeado corregedor. Mas a Relaçam diaria declara, em seu desfecho, ser da lavra de "testemunha de vista". MACHADO, Diogo Barbosa. Bibliotheca Lusitana, Historica, Critica, e Cronologica. Lisboa: Officina de Isidoro da Fonseca, 1741. t. I. p. 215-218.

63 "Esta Relacion verdadera del ultimo, i maior sucesso de la guerra del Brasil (tan maravilloso, como todos los otros, con que Dios ha testificado, que es voluntad suya establecer esta Corona de Portugal en la persona, i sucession del Rey D. JUAN el IV nuestro Señor) escrive un Portugues en lengua Castellana, para que nuestros enemigos la entiendan, i para que tenga mucho de notoria, pues tiene todo de verdadera”. ANÔNIMO, Relacion verdadera de la recuperacion de Pernambuco, sitio de su Recife. Lisboa: Officina Craesbeeckiana, 1654. ${ }^{64}$ ANÔNIMO. La victoire remportee par les portugais sur les holandois, dans le Brésil. Paris: Bureau d'Adresse, 1654.
} 
O fim da guerra não trouxe o fim da historicização, iniciada com as relaçóes de sucessos e relaçóes historiais compostas desde 1625. Não por acaso, Vieira e sua facção patrocinarão pelo quarto de século seguinte a fixação de sua versão do conflito, não mais em panfletos, mas em histórias impressas em in-quartos e in-folios, formatos editoriais de muito mais prestígio. Nelas, o enredo formulado nas relaçóes será ciosamente reformado, de maneira que, mesmo após a chegada de Barreto de Menezes a Pernambuco, Vieira é pintado como eminência parda no comando efetivo das forças, por reivindicação do oficialato e da soldadesca. As "narrativas vieirianas" de Diogo Lopes Santiago e de frei Raphael de Jesus serão clara, embora tardia resposta à secundarização do grupo local nas relaçóes do fim da guerra, em vista das ambiçóes materiais e simbólicas da açucarocracia, por conta dos muitos serviços que avaliava ter prestado.

Esse tardio contra-ataque discursivo vieiriano, iniciado já nos anos 1650 e vindo a lume durante a regência de d. Pedro II (1667-1683), triunfará ao ponto de reverter a historicização iniciada nas relaçóes desfavoráveis do período 1649-1654. A tríade central da narrativa vieiriana (além do Valeroso Lucideno, a Historia da Guerra de Pernambuco, iniciada antes de 1656 e concluída em data incerta, e o Castrioto Lusitano, publicado em 1680) será lida pelos eruditos setecentistas, em Portugal e no Brasil. Admitindo em seus escritos a narratio formulada por esses e outros autores seiscentistas, esses leitores-autores não se darão à labuta de recontar a Guerra Holandesa, dando a tarefa como já realizada por seus predecessores, e somente se ocuparão de integrá-la à história do reino ou da América Portuguesa. Borges da Fonseca, por exemplo, produzirá suas investigaçóes genealógicas em diálogo com aquelas fontes e Loreto Couto, ao compor seus Desagravos do Brasil, as consultará à larga ${ }^{65}$ É nessa retomada que a memória de Fernandes Vieira e de seus partidários floresce: sem embargo de críticas pontuais à "lisonja" de seus panegiristas, o saldo final é sua inclusão no centro do panteão dos heróis daquela guerra. As batalhas que chefiou, como Tabocas e Casa Forte, ascendem ao mesmo patamar das vitórias dos Guararapes. Vieira, Negreiros e seus aliados alcançam post mortem o status heroico na memória da guerra. Mesmo no século XIX, quando Varnhagen esforça-se por despedaçar a imagem gloriosa de Vieira — sem, no mais, romper com a narratio seiscentista ${ }^{66}$ — só o fará, com sucesso aliás bastante modesto, perante o imponente vulto que sua figura conquistara.

\footnotetext{
${ }^{65}$ MELLO, Evaldo Cabral de. Rubro veio: o imaginário da Restauração Pernambucana. São Paulo: Alameda, 2008, op. cit., p. 64 e ss. CLEMENTINO, Kleber. Politica e historiografia nas narrativas lusocastelhanas seiscentistas da Guerra Holandesa, op. cit., cap. 1.

${ }^{66}$ CLEMENTINO, Kleber. Herótodo de mentirinha: Varnhagen, a escrita da história da Guerra Holandesa e seu diálogo com as obras dos séculos XVII, XVIII e XIX, op. cit.
} 


\section{Referências}

\section{Fontes}

ANÔNIMO. Carta cierta y verdadera que vino a un cavallero desta ciudad, desde la Ciudad de San Lucar, haziendole Relacion de la cóficion que hizo un Maestre de una Nao que cogio el Armada del Almirantazgo, en que declarò, que el Brasil estava ya por el Rey Nuestro señor, y como le quemaron sus Naos, y passaró a cuchillo ochocientos hombres $q$ dentro avia. Sevilha: por Juan de Cabrera, 1625.

ANÔNIMO. La defaite navale de trois mil, tant Espagnols que Portugais, mis \& taillez en pieces par les Hollandois, à la Baya de Todos los Sanctos. Traduite de Flamand en François. Paris: por Jean Martin, 1625.

ANÔNIMO. La victoire remportee par les portugais sur les holandois, dans le Brésil. Paris: Bureau d'Adresse, 1654.

ANÔNIMO. Relaçam diaria do sitio, e tomada da forte praça do Recife, recuperação das capitanias de Itamaracà, Paraiba, Rio Grande, Ciará, \& Ilha de Fernão de Noronha, por Francisco Barreto Mestre de campo general do Estado do Brasil, \& Governador de Pernambuco. Lisboa: Officina Craesbeckiana, 1654.

ANÔNIMO. Relaçam verdadeira de tudo o succedido na Restauração da Babia de todos os Sanctos desde o dia em que partiram as armadas de S. Magestade, até o em que em a dita Cidade foram arvorados seus estandartes có grande gloria de Deus, exaltação do Rei e Reino, nome de seus vassallos, que nesta empresa se acharam, anibilaçam, e perdas dos rebeldes Olandezes ali domados. Lisboa: por Pedro Craesbeek, 1625.

ANÔNIMO. Relaçam verdadeira, e breve da tomada da villa de Olinda, e lugar do Recife na costa do Brazil pellos rebeldes de Olanda, tirada de huma carta que escreueo hum Religioso de muyta authoridade, \& que foy testemunha de vista de quasi todo o socedido: \& assi o affirma, \& jura; \& do mais que depois disso socedeo tè os dezoito de Abril deste prezente, \& fatal anno de 1630. Lisboa: por Mathias Rodrigues, 1630.

ANÔNIMO. Relacion de la victoria que alcanzaron las armas Catolicas en la Baia de Todos Santos, contra Olandeses, que fueron a sitiar aquella Plaça, en 14. de junio [sic] de 1638. Madri: Francisco Martinez, 1638.

ANÔNIMO. Relacion de la victoria que los Portugueses de Pernambuco alcançaron de los de la Compañia del Brasil en los Garerapes a 19. de Febrero de 1649. Viena: [sem ind. de impressor], 1649.

ANÔNIMO, Relacion verdadera de la recuperacion de Pernambuco, sitio de su Recife, entrega suya, i de las Capitanias de Itamaracá, Paraiba, Rio Grande, Ciará, e Isla de Fernando de Noronha, todo rendido a las armas Portuguesas regidas por Francisco Barreto Maesse de 
Canpo [sic] general del Estado del Brasil, i Governador de Pernambuco. Lisboa: Officina Craesbeeckiana, 1654.

ANÔNIMO. Relation veritable de la prinse de la Baya de todos los Santos, o de la ville de S. Sauneur au Brasil par la flotte hollandoie. Sem colofăo, 1624.

ANÔNIMO. Sucessos de la armada que fue al Brasil, y el largo viaje que tuvieron por tierra. Dase cuenta de los encuentros que tuvieron con el Olandes. Sevilha: por Nicolas Rodriguez, 1640.

ANÔNIMO, Successo della guerra de Portugueses levantados em Pernambuco contra Olandeses, como por carta del Maestro de Campo Martino Soarez, et Andrea Vidal de Negreiros, por Antonio Telles da Silva. El Anno 1646. Sem colofão ou data.

AVEDAÑ̃ Y VILELA, Francisco de. Relacion del viaie, y sucesso de la Armada que por mandado de su Magestad partio ao Brasil, a echar de alli los enemigos que lo ocupavan. Sevilha: por Francisco de Lyra, com licença, 1625.

BURGOS, Bartolomé Rodriguez de. Relacion de la iornada del Brasil, escrita a Ivan de Castro Escrivano Publico de Cadiz, por Bartolome Rodriguez de Burgos Escrivano mayor de la Armada. Cádiz: por Juan de Borja, 1625.

CALADO, Manuel. O valeroso Lucideno, e Triumpho da Liberdade. Primeira parte. Lisboa: por Paulo Craesbeeck, 1648.

GUERREIRO, Bertolameu. Jornada dos Vassalos da Coroa de Portugal, pera se recuperar a cidade do Salvador, na Bahya de Todos os Santos, tomada pollos Olandezes, a oito de mayo de 1624, \& recuperada ao primeiro de mayo de 1625. Lisboa: Por Matheus Pinheiro, 1625.

OSÓRIO, d. Fadrique de Toledo. Relacion de la carta que embio a su Magestad el Señor don Fadrique de Toledo, general de las Armadas, y poderoso exercito, que fue al Brafil, y del felicissimo fucesso, que alcançaron en dia de los gloriosos Apostoles $S$. Felipe, $Y$ Santiago, que fue a primero de Mayo, deste año de 1625. Sevilha: por Simon Faxardo, com licença do senhor tenente D. Luís Ramirez, 1625.

ROSÁRIO, Paulo do. Relaçam breve, e verdadeira da memoravel victoria que ouve o capitáo mor da capitania da Paraiva Antonio de Albuquerque, dos rebeldes de Olanda, que são vinte naos de guerra, \&u vinte \& sete lanchas: pretenderäo occupar esta praça de sua Magestade, trazendo nellas para o effeito dous mil homens de guerra escolhidos afora a gente do mar. Lisboa: por Jorge Rodrigues, 1632.

VARNHAGEN, Francisco Adolfo de. História das lutas contra os holandeses no Brasil desde 1625 até 1654. Lisboa: Typographia de Castro Irmão, 1872. 


\section{Obras consultadas}

ALMEIDA, Horácio de. História da Paraíba. João Pessoa: Imp. Universitária, 1966. t. I. AROUCHA, Marcone Zimmerle. Serviço e nobilitação: a dinastia bragantina e as concessóes de foro de fidalgo no Atlântico Sul (1640-1680). Dissertação (Mestrado em História) Universidade Federal de Pernambuco, Recife, 2015.

BEBIANO, Rui. A pena de Marte: escrita da guerra em Portugal e na Europa (sécs. XVIXVIII). Coimbra: Minerva, 2000.

BÉGAND, Patrick (Ed.). Las relaciones de sucesos: relatos fácticos, oficiales y extraordinarios. Besançon: Presses Universitaires de Franche Comté, 2006.

BOXER, Charles R. O império marítimo português (1415-1825). São Paulo: Companhia das Letras, 2002.

BOUZA ÁLVAREZ, Fernando J. Del escribano a la biblioteca: la civilización escrita europea en la Alta Edad Moderna (siglos XV-XVIII). Madri: Síntesis, 1997. p. 9-23.

BOUZA ÁLVAREZ, Fernando J. Portugal no tempo dos Filipes (1580-1668). Lisboa: Ediçôes Cosmos, 2000.

CAMENIETZKI, C. Ziller; PASTORE, G. Grassia. 1625, o fogo e a tinta: a batalha de Salvador nos relatos de guerra. Topoi, Rio de Janeiro, v. 6, n. 11, p. 261-288, jul./dez. 2005. CAROLINO, Luís Miguel. A escrita celeste: almanaques astrológicos em Portugal nos séculos XVII e XVIII. Rio de Janeiro: Acess, 2002.

CLEMENTINO, Kleber. Heródoto de mentirinha: Varnhagen, a escrita da história da Guerra Holandesa e seu diálogo com as obras dos séculos XVII, XVIII e XIX. Clio, n. 32.2, p. 128-152, jul./dez. 2018.

CLEMENTINO, Kleber. Politica e historiografia nas narrativas lusocastelhanas seiscentistas da Guerra Holandesa no Atlântico Sul. Tese (Doutorado em História) - Programa de Pósgraduação, Universidade Federal de Pernambuco, Recife, 2016.

ELLIOTT, John. El conde-duque de Olivares: el político en una época de decadencia. Barcelona: Crítica, 2010.

ETTINGHAUSER, Henry. The news in Spain: Relaciones de sucesos in the reigns of Philip III and IV. European History Quarterly, v. 14, p. 1-20, 1984.

GINZBURG, Carlo. Relações de força: história, retórica, prova. São Paulo: Companhia das Letras, 2002.

LANCIANI, Giulia. Sucessos e naufrágios das naus portuguesas. Lisboa: Caminho, 2007.

LEITE, Jorge Miranda. O dito e o feito: heróis exemplares nos relatos de guerra na Restauração pernambucana (1630-1654). Dissertação (Mestrado em História) — Programa de Pósgraduação, Universidade Federal Fluminense, Niterói, 2009. 
MACHADO, Diogo Barbosa. Bibliotheca Lusitana, Historica, Critica, e Cronologica. Lisboa: Officina de Isidoro da Fonseca, 1741. t. I.

MAGALHÃES, Pablo A. Iglesias. Equus rusus: a Igreja Católica e as Guerras Neerlandesas na Bahia (1624-1654). Tese (Doutorado em História) — Programa de Pós-graduação, Universidade Federal da Bahia, Salvador, 2010.

MAGALHÁES, Pablo A. I. A Relacion de la victoria que alcanzaron las Armas Catolicas en la Baia de Todos Santos, do Bispo D. Juan de Palafox y Mendonza. Topoi, v. 12, n. 23, p. 43-65, jul./dez. 2011.

MARTINS, Maria T. E. Payan. A censura literaria em Portugal nos séculos XVII e XVIII. Lisboa: Fundação Calouste Gulbenkian, 2005.

MARQUILHAS, Rita. A faculdade de letras: leitura e escrita em Portugal no século XVII. Lisboa: Imprensa Nacional — Casa da Moeda, 2000.

MEGIANI, Ana Paula Torres. Contar coisas de todas as partes do mundo: as Relaciones de Sucesos e a circulação de notícias escritas no período filipino. In: ALMEIDA, Suely Creusa Cordeiro; RIBEIRO, Marília de Azambuja et al. (Org.). Cultura e sociabilidades no mundo atlântico. Recife: Ed. Universitária da UFPE, 2012.

MEGIANI, Ana Paula Torres. O rei ausente: festa e cultura política nas visitas dos Filipes a Portugal (1581-1619). São Paulo: Alameda, 2004.

MELLO, Evaldo Cabral de. O negócio do Brasil: Portugal, os Países Baixos e o Nordeste (1641-1669). Rio de Janeiro: Topbooks, 1998.

MELLO, Evaldo Cabral de. Rubro veio: o imaginário da Restauração Pernambucana. São Paulo: Alameda, 2008.

MEGIANI, Ana Paula Torres. Olinda restaurada: guerra e açúcar no Nordeste, 1630-1654. São Paulo: Editora 34, 2007.

NETSCHER, Pieter Martinus. Les Hollandais au Brésil, notice historique sur les Pays-Bas et le Brésilau XVIIe siècle. Haia: Irmãos Belifante, 1853.

PENA SUEIRO, Nieves. Estado de la cuestión sobre el estudio de las Relaciones de sucesos. Rev. Pliegos de Bibliografia, Madri, n. 13, p. 1-19, 1ํo semestre de 2001.

PEREIRA, Ana M. Alejandro Farnese en las relaciones de sucesos españolas. In: CARVAlHO, José Adriano de Freitas (Dir.). D. Maria de Portugal: princesa de Parma (1538-1577) e o seu tempo. Porto: Inst. de Cultura Portuguesa, 1999.

POCOCK, John G. Linguagens do ideário político. São Paulo: Edusp, 2013.

RAU, Virgínia. A primeira Batalha dos Guararapes descrita por André Vidal de Negreiros. Coimbra: Coimbra Ed., 1955 (Separata da Brasília, v. IX).

RAULT, Didier. La información y su manipulación em las relaciones de sucesos. Encuesta sobre dos relatos de batallas navales entre españoles y holandeses (1638). Rev. Criticón, 
Toulouse, n. 86, p. 97-115, 2002.

RODRIGUES, J. Honório. Historiografia e bibliografia do dominio holandês no Brasil. Rio de Janeiro: Dep. de Imprensa Nacional, 1949. p. 190 e ss.

SCHWARTZ, Stuart. B. The Voyage of the Vassals: Royal Power, Noble Obligations and Merchant Capital before the Portuguese Restoration of Independence (1624-1640). The American Historical Review, v. 96, p. 735-762, n. 3, jun. 1991.

SOUSA, J. Pedro (Coord.). A gênese do jornalismo lusófono e as relaçóes de Manuel Severim de Faria (1626-1628). Porto: Ed. da Universidade Fernando Pessoa, 2007.

USUNÁRIZ, Jesus M. América, la política internacional europea y las "relaciones de sucesos" españolas tras los tratados de Westfalia. Rev. Chilena de Literatura, Santiago, n. 85, p. 179-201, nov. 2013.

TEENSMA, B. N (Ed.). Brasil holandês: dois manuscritos portugueses sobre a conquista neerlandesa (1624) e a reconquista lusoespanhola (1625) de Salvador da Bahia no Brasil. Rio de Janeiro: Index, 1999.

VAN GROESEN, Michiel. Amsterdam's Atlantic: Print Culture and the Making of Dutch Brasil. Filadélfia: University of Pennsylvania Press, 2017.

VARELA, Laura Beck. Literatura jurídica y censura: fortuna de Vinnius en España. Valencia: Tirant, 2013. 